\section{Bangladesh: Grameen Bank's Higher Education Loan Pro-} gram

\section{Richard Hopper}

Richard Hopper is on the staff of the World Bank, Washington, D.C. Email: <Richard_Hopper@gse.harvard.edu>.

$\mathrm{I}_{\mathrm{t}}^{\mathrm{n}}$ a climate of government disinterest in higher education equity in developing countries, one nongovernmental organization (NGO) in Bangladesh has unexpectedly begun its own effort at financial aid in the higher education sector. Grameen Kalyan, the welfare division of Grameen Bank, famous since 1983 for its innovative lending programs for the landless poor, has expanded its objectives beyond microenterprise to include higher education. The managing director of Grameen Kalyan, Shaikh Abdud Daiyan, states that NGOs must now begin to "consider the economy of the poor-and help them to rise to the highest levels of education." Grameen Kalyan has devised a program-the Higher Education Loan Program (HELP) - that identifies intellectually talented young villagers and helps them to finance their university education through loans. Using Grameen Bank's network of 1,118 branch offices throughout rural Bangladesh, Grameen Kalyan wants to encourage poor children not only to complete the equivalent of secondary education, but also to attend public university. The hope is to create a new generation of highly educated poor who will have one more weapon with which to attack the cycle of poverty. In the context of Bangladesh, one of the least-developed countries in the world, such a task would seem enormous if not impossible.

Branch officers of Grameen Bank canvass their local communities and encourage adult borrowers from Grameen microcredit programs to identify the most promising children for student loan consideration. Due to the lack of formal schooling opportunities in some rural areas of Bangladesh, many candidates emerge from nontraditional educational programs (often organized by nongovernmental organizations). Even if a poor nontraditional student gains admission to university, expenses associated with studying at that level in Bangladesh can easily surpass $\$ 400$ per year-an astronomical sum for the sons and daughters of rural families that typically live in grass huts and survive on less than one dollar per day. To be eligible, applicants for HELP loans must be the dependents of Grameen Bank borrowers, the poor without assets who have qualified for a loan through the bank's existing microcredit program. Under Grameen's definition, a dependent is not necessarily a child related through birth, but can also in- clude a child "who eats regularly from the same pot"-an important criterion in rural Bangladesh, where village families often share food and child-rearing responsibility. Most Grameen borrowers are women-fully 94 percent. All Grameen borrowers are considered "members" of the bank.

The loan qualifications for first-time "members" at Grameen run counter to the lending criteria of traditional banks: rather than having to show collateral or income to guarantee repayment, Grameen borrowers must demonstrate poverty and propose an income-generating activity that they will establish with their first loan, at market interest rates. The average loan dispersed by Grameen Bank is approximately $\$ 195$. As part of their loan agreement, borrowers must join a local five-member group that meets each week and assumes collective responsibility for the other group-member loans. Groups are free to add members, but they must conduct the initial screening of borrowers for Grameen, further strengthening the internal system of accountability and support. Groups, therefore, expand carefully and look for trustworthiness and cooperation as the main criteria to expand their borrowing circles. Borrowers contribute a very modest membership fee to Grameen Bank for each loan, giving them small, yet important, shares of ownership in the bank. This membership system has actually shifted the majority ownership of Grameen from the donor agencies and government to the individual borrowing members, who now control fully 92 percent of the shares-up from only 40 percent in 1983 . After a first-time borrower of Grameen repays her loan, she obtains a guarantee of lifelong credit from the bank. Today, Grameen members have an added benefit: the opportunity to have their dependents eligible for HELP.

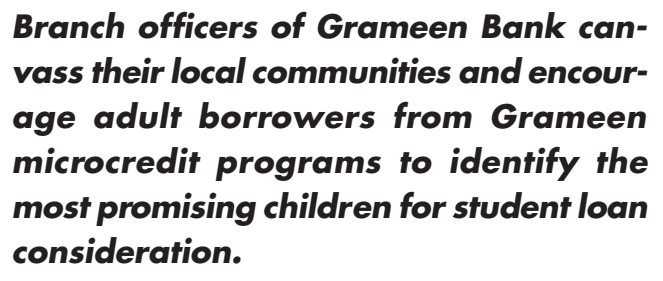

In 1998, the first year of the program, the welfare division of Grameen dispersed loan installments averaging $\$ 400$ per person and bearing 5 percent simple interest-a much lower interest rate and easier terms than for the standard Grameen microcredit loans. The 65 student loan recipients identified and selected by Grameen Bank branch officers are currently working toward degrees in subjects as diverse as medicine, engineering, business administration, agriculture, humanities, and the social sciences. 
Though the time to degree at the public universities in Bangladesh is generally from three to five years, these students will receive annual HELP loans until graduation, as long as they maintain good academic standing. Loan recipients will therefore incur an average total indebtedness of more than $\$ 1,200$. Grameen expects graduates to begin repaying their loans just one year after completion of their respective degree programs, with a total of five years to complete the repayment schedule. Officials at Grameen believe this ambitious loan program provides a "rare chance for the poor to rise up to the highest levels of the employment market ... [the results of which] will be felt in the villages [as the graduates] do their part to assist their home communities." Clearly, providing multiple collateral-free loans to extremely poor students for a long course of study involves many risks, not the least of which is the specter of default. Grameen Kalyan seems prepared to assume these risks.

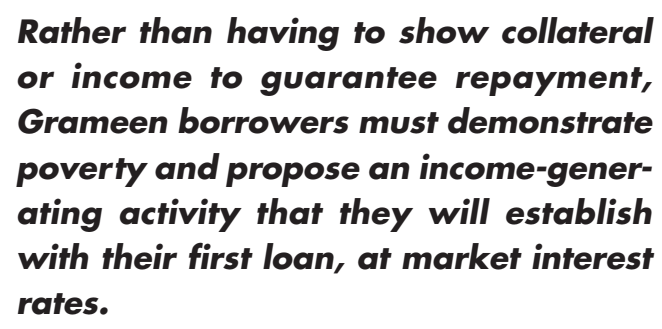

Previous research on higher education loans in developing countries has produced some generally disappointing findings about the success of such programs, revealing problems in administration, management, and loan recovery. Scholars in education suggest that the most likely reasons for program failure are high default rates and the institutional expense of interest subsidies prior to repayment. Also, there is understandable concern about saddling the poor with years of debt. Student loan programs in other developing countries have typically targeted a segment of the middle class. The impact of such a great financial liability on the lives of very poor graduates has yet to be assessed. The student loan programs recently examined in developing countries were almost all created and managed by governments. One study sponsored by the World Bank proposes that loan defaults might be reduced if private institutions with the capacity to collect payments managed the programs. ${ }^{1}$ Grameen Bank represents just such an institution.

Dr. Muhammad Yunus, founder and managing director of Grameen Bank, considers most poverty alleviation efforts made by governments and other NGOs to be pal- liative rather than empowering, providing only stop-gap measures instead of offering sustainable self-help solutions to the poverty cycle. He has been traveling around the world for nearly two decades, seeking to convince others that the poor are creditworthy. Yunus cites Grameen's 16 years of experience in small loans to more than two million poor in Bangladesh to encourage the growth of income-generating activities. According to internal estimates, the bank maintains a 97 percent loan-recovery rate through its community-based system of accountability, which has produced what is widely considered "the most successful self-sustaining antipoverty program in the world." ${ }^{2}$ The Grameen model of microcredit has spawned more than 200 replication programs in more than 50 countries, including the United States. Grameen Kalyan already has plans to double the number of its student loans in the next year and hopes that HELP will serve as a model for other NGOs in the Third World.

Might the Grameen Higher Education Loan Program actually be a good equity prototype for other developing countries? At this time it is difficult to say. The recovery outcomes of this nongovernmental student loan initiative in Bangladesh cannot be fully assessed for many years, since the initial beneficiaries of these loans are just nearing the end of their first year of university studies. However, it is important to note that repayment is not the sole measure of success. Grameen's approach must be judged on many levels, and perhaps most significantly on its dedication to identifying and supporting the poorest of the poor. This mission is no small feat when the target population typically lives in a grass shelter, subsists on agricultural production, and has minimal access to educational resources at the basic and secondary levels. According to Daiyan, "The chance for the brightest children from these poorest areas to rise to this level of society is extremely rare. We want to see this program grow. My only worry is the possible unemployment of graduates. Having come from poor families, however, these students are very resourceful." In spite of their apparent resourcefulness, loan recipients still face the looming specter of high unemployment in Bangladesh. In addition to HELP, Grameen will likely need to develop a parallel program to aid its loan recipients in finding and maintaining jobs. If Grameen is successful in the employment of its graduates, this nongovernmental organization will likely have created a higher education equity program worth replicating.

\section{Notes}

1. Douglas Albrecht and Adrian Ziderman, "Student Loans and Their Alternatives," Higher Education 23 (1992): 357-74.

2. David Bornstein, The Price of a Dream: The Story of the Grameen Bank (Dhaka, Bangladesh: University

Press Limited, 1996). 